\title{
Evaluation of soil fertility and fertilisation practices for irrigated maize (Zea mays L.) under Mediterranean conditions in central Chile
}

\author{
F. Nájera ${ }^{1}$, Y. Tapia ${ }^{1}$, C. Baginsky ${ }^{2}$, V. Figueroa ${ }^{2}$, R. Cabeza ${ }^{1}$, and O. Salazar ${ }^{1 *}$ \\ ${ }^{1}$ Departamento de Ingeniería y Suelos, Facultad de Ciencias Agronómicas, Universidad de Chile, La Pintana, \\ Santiago, Chile. ${ }^{2}$ Departamento de Producción Agrícola, Facultad de Ciencias Agronómicas, Universidad de \\ Chile, La Pintana, Santiago, Chile. "Corresponding author: osalazar@uchile.cl
}

\begin{abstract}
The main aim of this study was to carry out an evaluation of soil fertility and fertilisation practices for irrigated maize (Zea mays L.) under Mediterranean conditions in central Chile. Soil samples were collected from 31 maize fields for macro- and micronutrient analysis; additionally a crop management survey was carried out in each field. These data were used to identify the range of critical soil-test concentrations of nutrients and the relationships among these soil fertility parameters; to assess the relationship between maize yields and nutrient status of soils; to evaluate the current fertiliser practices of farmers comparing them with nitrogen $(\mathrm{N})$, phosphorus (P) and potassium (K) fertiliser model calculations; and to analyse whether The results showed that there was a dominance of neutral-alkaline soils with low organic matter and $\mathrm{N}$ levels, and high $\mathrm{P}$, cations and micronutrient levels. Regression analysis explained at least $59 \%$ of the variation in maize yields, when soil $\mathrm{pH}$ and available zinc $(\mathrm{Zn})$ content were identified as the most important variables controlling maize yield. Results suggest that in neutral-alkaline soils cultivated with maize and high inputs of N-P-K, there may be a maize yield response to $\mathrm{Zn}$ applications. It was found that most farmers over-fertilised with $\mathrm{N}$ (from 60 to $360 \mathrm{~kg} \mathrm{~N}$ ha $^{-1}$ ) and $\mathrm{P}$ (from 10 to $120 \mathrm{~kg} \mathrm{P}_{2} \mathrm{O}_{5} \mathrm{ha}^{-1}$ ), converting maize fields in an important non-point source of pollution of water bodies in central Chile.
\end{abstract}

Keywords: Soil nutrition, fertiliser, nitrogen, phosphorus, water quality, zinc

\section{Introduction}

Maize (Zea mays L.) is the third most important crop worldwide after rice (Oryza sativa L.) and wheat (Triticum aestivum L.). In Chile during the 2012-2013 season, maize covered approximately 140.000 ha, producing 1.4 million tons grain, representing $20 \%$ of the total annual crop surface with a mean yield of 13 ton $\mathrm{ha}^{-1}$, which is one of the highest yielding in the world. This is largely due to the favourable Mediterranean climate conditions of temperature and solar radiation. Furthermore, in Chile maize is cultivated using conventional irrigation systems during the growing season. 
To maintain these high yields farmers need to apply high levels of nitrogen $(\mathrm{N})$, phosphorus $(\mathrm{P})$, potassium (K) and other nutrients. However, soil analyses are not extensively used by maize small farmers in central Chile to determine N-P-K fertiliser doses. In contrast, most of them consider that applying fertiliser to a maize crop is a cost that can always generate a return within the current crop cycle. However, although $\mathrm{N}$ is the most important nutrient for crop production, and $\mathrm{N}$ fertilisation rates have been increasing in Chile in recent decades, in many cases, this has not resulted in a proportional increase in crop yields (Casanova et al., 2013). Clearly this common approach to $\mathrm{N}$ fertiliser management not only reduces expected net returns but also increases the risk of over or under-fertilisation in maize fields, where soil-bas al., 2006). Therefore, it is important to provide to the farmer appropriate decision support tools that will allow them access to better $\mathrm{N}$ fertiliser recommendations (Robertson and Vitousek, 2009).

Recently, in Mediterranean zones of Chile there are further concerns because $\mathrm{N}$ and $\mathrm{P}$ over-fertilisation in irrigated maize fields can be associated with a high risk of diffuse pollution of water bodies (Casanova et al., 2013; Fuentes et al., 2014; Salazar et al., 2014). This is because in addition to applying high levels of $\mathrm{N}$ and $\mathrm{P}$ most of farmers utilise a furrow irrigation system with low application al., 2013). Similarly, in other Mediterranean areas in the world, irrigated maize fields with high $\mathrm{N}$ doses have been highlighted as at high risk of creating $\mathrm{N}$ diffuse pollution areas (Berenguer et al., 2009; Salmerón et al., 2012).

On the one hand, Casanova et al. (2013) reported that in the Mediterranean zone of Chile there are mainly neutral to alkaline soils, where on high-pH soils may occur nutrient deficiencies such as boron (B), copper $(\mathrm{Cu})$, iron (Fe), manganese (Mn) and zinc (Zn).In Particular, FAO (2006) noted that among the microelements, $\mathrm{Zn}$ deficiency is the most widespread problem in maize fields, mostly related to alkaline calcareous soils and soils with low organic matter content. On the other hand, Casanova et al. (2013) also found that the levels of soil organic carbon (SOC) stocks are usually low (SOC $<2.5 \%$ ) which could be mainly related to a biological degradation of soils occurring because most farmers usually burn the maize stalks after the harvest with a low recycling of nutrients from the crop residues. However, it could not be discarded a fast SOC mineralization under irrigated conventional tillage system with high temperature and soil humidity in the Mediterranean zone of Chile (Martínez et al., 2013). Good soil conditions in Mediterranean central Chile, e.g. deep, neutral $\mathrm{pH}$, low salt and sodium content (Casanova et al., 2013) suggest that maize yields would be increased if an adequate soil fertility program is implemented, for example through the support of state subsidies. However, there is a lack of information about the nutrient status of soils to facilitate the implementation of better soil fertility practices. The main aim of this study was to carry out an evaluation of soil fertility and fertilisation practices for irrigated maize (Zea mays L.) under Mediterranean conditions in central Chile. Some specific objectives of this study were $(i)$ to identify the range of critical soil-test concentrations of $\mathrm{N}$, $\mathrm{P}, \mathrm{K}, \mathrm{Ca}, \mathrm{Mg}, \mathrm{B}, \mathrm{Cu}, \mathrm{Fe}, \mathrm{Mn}$ and $\mathrm{Zn}$ and the relationships among these soil fertility parameters in soils cultivated with maize; (ii) to assess the relationship between maize yields and nutrient status of soils; (iii) to evaluate the current fertiliser practices of farmers comparing them with N-P-K fertiliser model calculations; and (iv) to analyse whether the current $\mathrm{N}$ and $\mathrm{P}$ fertiliser practices represent an environmental risk due to over fertilisation.

\section{Materials and Methods}

\subsection{Site description}

The study was carried out on 31 maize fields located in the communes of Pichidegua $\left(34^{\circ} 21^{\prime} \mathrm{S}, 71^{\circ} 16^{\prime} \mathrm{W}\right.$,

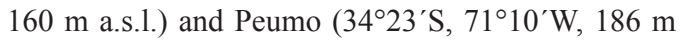
a.s.1.) in central Chile (Table 1). Maize was sown in 
spring (September-October 2012) and harvested in autumn (March-April 2013). Usually, a commercial hybrid maize adapted to this area are drilled with 10 $13 \mathrm{~cm}$, regarding spacing between rows of $75 \mathrm{~cm}$, for an anticipated stand of about 95.000 plants ha ${ }^{-1}$. In these fields the maize grain yields ranged from 11 to $18 \mathrm{t} \mathrm{ha}^{-1}$. During the growing season the maize was irrigated using a furrow system with low water use efficiency $(<45 \%)$, where approximately 18.000 $\mathrm{m}^{3} \mathrm{ha}^{-1}$ were applied during the crop cycle.

All fields included in this study have a climate described as semi-arid Mediterranean, with hot summers and relatively cold winters, a mean annual air temperature of $14.9^{\circ} \mathrm{C}\left(29.0^{\circ} \mathrm{C}\right.$ in January and $4.9^{\circ} \mathrm{C}$ in July $)$ and a mean annual precipitation of around $700 \mathrm{~mm}$, mostly falling between May and October.

Table 1. Soil classification and textural classes

\begin{tabular}{|c|c|c|c|}
\hline $\mathrm{N}^{\circ}$ & Soil Serie $^{a}$ & $\begin{array}{l}\text { Soil Taxonomy } \\
\text { (Subgroups) }^{\mathrm{b}}\end{array}$ & Textural classes \\
\hline 1 & Patagua & Typic Palexerolls & Clay \\
\hline 2 & Patagua & Typic Palexreolls & Clay \\
\hline 3 & Patagua & Typic Palexroells & Clay loam \\
\hline 4 & Patagua & Typic Palexerolls & Clay \\
\hline 5 & Peumo & Fluventic Haploxerolls & Loam \\
\hline 6 & Patagua & Typic Palexerolls & Clay loam \\
\hline 7 & Palquiales & Abruptic Argiaquolls & Clay loam \\
\hline 8 & Talhuen & Typic Duraqualfs & Sandy loam \\
\hline 9 & Talhuen & Typic Duraqualfs & Clay loam \\
\hline 10 & Talhuen & Typic Duraqualfs & Clay loam \\
\hline 11 & Talhuen & Typic Duraqualfs & Clay loam \\
\hline 12 & Cocalan & Aquic Haploxerolls & Loam \\
\hline 13 & Palquiales & Abruptic Argiaquolls & Sandy loam \\
\hline 14 & Huique & Typic Calcixererts & Clay \\
\hline 15 & Patagua & Typic Palexerolls & Clay \\
\hline 16 & Toco & Abruptic Durixeralfs & Loam \\
\hline 17 & Talhuen & Typic Duraqualfs & Sandy loam \\
\hline 18 & Caleuche & Typic Duraqualfs & Sandy clay loam \\
\hline 19 & Caleuche & Typic Duraqualfs & Clay \\
\hline 20 & Caleuche & Typic Duraqualfs & Clay \\
\hline 21 & Caleuche & Typic Duraqualfs & Clay \\
\hline 22 & Talhuen & Typic Duraqualfs & Loam \\
\hline 23 & Palquiales & Abruptic Argiaquolls & Sandy loam \\
\hline 24 & Palquiales & Abruptic Argiaquolls & Sandy loam \\
\hline 25 & Palquiales & Abruptic Argiaquolls & Clay \\
\hline 26 & Palquiales & Abruptic Argiaquolls & Loam \\
\hline 27 & Cocalan & Aquic Haploxerolls & Loam \\
\hline 28 & Palquiales & Abruptic Argiaquolls & Clay \\
\hline 29 & Caleuche & Typic Duraqualfs & Clay loam \\
\hline 30 & Palquiales & Abruptic Argiaquolls & Sandy loam \\
\hline 31 & Talhuen & Typic Duraqualfs & Sandy loam \\
\hline
\end{tabular}

${ }^{a}$ According to CIREN (2002).

${ }^{\mathrm{b}}$ According to Soil Survey Staff (2014). 


\subsection{Soil sampling and analyses}

In each field, soil samples were collected at $0-20 \mathrm{~cm}$ depth intervals during September 2012 before maize was sown and a composite soil sample of 10 to 20 constituent samples was collected. The soil samples were dried at room temperature and sieved at 2-mm. Chilean standard methods for chemical soil analysis according to Sadzawk et al. (2006) were used for measuring soil fertility parameters that may have a direct impact in the maize yield in the study area, such as: available nitrogen $\left(\mathrm{NO}_{3}+\mathrm{NH}_{4}\right)$ by $\mathrm{KCl}$ extraction and steam distillation system Kjeldahl, available phosphorus (P) by Olsen test; available potassium (K) and exchangeable calcium $(\mathrm{Ca})$ and magnesium $(\mathrm{Mg})$ extracted with ammonium acetate at $\mathrm{pH}$ 7; boron (B) by hot water method; extractable copper $(\mathrm{Cu})$, iron $(\mathrm{Fe})$, manganese $(\mathrm{Mn})$ and zinc $(\mathrm{Zn})$ by the DTPA method; soil $\mathrm{pH}$ was determined in a 1:2.5 soil: water ratio; and soil organic matter (OM) by calcination $\left(360^{\circ} \mathrm{C}\right)$. Sulphur $(\mathrm{S})$ was not included because most soils in the study area present high available $\mathrm{S}$ status (available $\mathrm{S}>12 \mathrm{ppm}$ ) due to $\mathrm{S}$ addition by irrigation water. In addition, soil texture was determined by the hydrometer method (Sandoval et al., 2012). The results of chemical soil analyses were classified according different standards used in Chilean soils (see Table2), whereas soil reaction $(\mathrm{pH})$ was classified as: ultra acidic $(<3.5)$, extremely acidic $(3.5-4.4)$, very strongly acidic (4.5 - 5.0), strongly acidic (5.1 $5.5)$, moderately acidic (5.6 - 6.0), slightly acidic (6.1 - 6.5), neutral (6.6 - 7.3), slightly alkaline (7.4 - 7.8), moderately alkaline (7.9 - 8.4), strongly alkaline (8.5 - 9.0) and very strongly alkaline (>9.0).

\subsection{Optimum dose of $\mathrm{N}-\mathrm{P}-\mathrm{K}$ fertilisers}

A survey regarding maize yields, fertilisation and soil management from March-April 2013 was conducted for each field. During this time farmers applied two types of fertilisers: a mixed fertiliser $25-10-10(\% \mathrm{~N}$ - $\% \mathrm{P}_{2} \mathrm{O}_{5}-\% \mathrm{~K}_{2} \mathrm{O}$, respectively) at planting using subsurface band and urea (46-0-0) and side-dressing after planting, which supplied between 350 to $560 \mathrm{~kg}$ $\mathrm{Nha}^{-1}, 75$ to $90 \mathrm{~kg} \mathrm{P}_{2} \mathrm{O}_{5} \mathrm{ha}^{-1}$ and 75 to $90 \mathrm{~kg} \mathrm{~K}_{2} \mathrm{O} \mathrm{ha}^{-1}$. For comparison between common farmer fertiliser rates and calculated N-P-K doses based on maize demand and available N-P-K soil status the following equations were used: $(i)$ to calculate the $\mathrm{N}$ dose Stanford's classic approach was used that included a mass $\mathrm{N}$ balance for assessing crop $\mathrm{N}$ fertiliser needs by considering $\mathrm{N}$ uptake at a specific dry matter yield level and $\mathrm{N}$ contributions from non-fertiliser sources. Thus the recommended $\mathrm{N}$ rate of fertiliser was calculated according to Equation (1):

$N$ demand $\left(\mathrm{kg} \mathrm{Nha}^{-1}\right)=\mathrm{Y} \times\left(1 \frac{\left.\frac{H}{100}\right) \mathrm{X} \frac{I N R}{100}}{H 1}\right.$

where: $Y$ is the grain yield $\left(\mathrm{kg} \mathrm{ha}^{-1}\right), H$ is grain moisture content (\%), INR is the internal nitrogen requirement (\%) and $H I$ is harvest index (-). $Y$ was estimated for each field according site conditions, including maize hybrid yield and soil factors such as soil depth and soil compaction. In addition $\mathrm{N}$ rate per hectare is calculated as Equation (2):

$N$ rate $\left(\operatorname{kg~Nha}\left({ }^{-1}\right)=\frac{N \text { demand }\left(\mathrm{kg} N \text { ha }\left({ }^{-1}\right)-N e t N \text { mineralization }\left(\mathrm{kg} \mathrm{Nha}\left({ }^{-1}\right)\right.\right.}{\frac{{ }^{N} E f}{100}}\right.$

where: $N_{E f}$ is the $\mathrm{N}$ fertiliser efficiency (\%), mostly depending on soil type and irrigation system, where Chilean studies suggest $E f$ values range from $50 \%$ to 65\% (Opazo et al., 2008); and the net $\mathrm{N}$ mineralisation potential of soils that depend on soil management and $\mathrm{N}$ recycling (see Table 3 ).

(ii) to calculate the $\mathrm{P}$ and $\mathrm{K}$ doses, the principle of the law of diminishing returns was used, assuming that as the nutrient status of the soil increases, the maize response to $\mathrm{P}$ and $\mathrm{K}$ fertilisation decreases, until 
the point where soil levels reach $20 \mathrm{mg}$ P-Olsenkg-1 and $150 \mathrm{mg}$ available- $\mathrm{K} \mathrm{kg}^{-1}$, these called critical values $(C V)$, when there is no response to fertiliser application.Thus $\mathrm{P}$ and $\mathrm{K}$ fertiliser rates can be calculated as shown in Equation (3) and Equation (4), respectively.

Prate $\left(k g P_{2} O_{5} h a\left(^{-1}\right)=\frac{\left(P_{c v}-P_{s d}\right) \times D b \times S D \times 2.29 \times 10}{\frac{{ }^{N} E f}{100}}\right.$

where: $P_{c v}$ is the critical value for P-Olsen in the soil (mg P-Olsen $\mathrm{kg}^{-1}$ ), $P_{s a}$ is the measured soil analysis value for P-Olsen in the soil (mg P-Olsen $\left.\mathrm{kg}^{-1}\right), D b$ is the estimated bulk density $\left(\mathrm{Mg} \mathrm{m}^{-1}\right), S D$ is soil depth (m) and $P_{E f}$ is $\mathrm{P}$ fertiliser efficiency (\%), where $P_{E f}$ is usually assumed around $60 \%$ in soils of central Chile.

$K$ rate $\left(\mathrm{kg} \mathrm{K} \mathrm{O}_{2} \mathrm{Oha}\left(^{-1}\right)=\frac{\left(K_{c v}-K_{s d}\right) \times D b \times S D \times 1.2 \times 10}{\frac{{ }^{N} E f}{100}}\right.$

where: $K_{c v}$ is the critical value for available $\mathrm{K}$ in the soil (mg K kg-1), $K_{s a}$ is the measured soil analysis value for available $\mathrm{K}$ on the soil $\left(\mathrm{mg} \mathrm{K} \mathrm{kg}{ }^{-1}\right)$ and $K_{E f}$ is $\mathrm{K}$ fertiliser efficiency (\%), where $K_{E f}$ ranges from $80 \%$ for fine-textured soils to $95 \%$ for coarse-textured soils depending on the degree of $\mathrm{K}$ adsorbed of clay particles on soils.

\subsection{Statistical analyses}

To identify relationships among soil fertility parameters Pearson's correlation matrices were calculated. In addition multiple regression models were developed using soil fertility assessment data to explain variation in maize yields, where a backward selection procedure was performed by deleting predictors from the existing model based on the F-test. The significance of the regression variables in the multiple linear regressions was evaluated through the calculation of an adjusted coefficient of determination
$\left(R_{a d j}^{2}\right)$. The analyses above were performed using Minitab 15.

\section{Results and Discussion}

\subsection{Properties and nutrient status of soils}

Results were related to the index of nutrient availability as shown in Table 2. Table1 shows the variability of soil texture in the studied soils, where a broad range of textural classes were found ranging from sandy loam to clay, which corresponds to Mollisols, Inceptisols and Alfisols according Soil Taxonomy (Soil Survey Staff, 2014).

Soil $\mathrm{pH}$ analyses showed that soils were classified as: slightly acidic ( $3 \%$ of the total), neutral $(55 \%$ of the total), slightly alkaline (39\% of the total) and moderately alkaline (3\% of the total). Clearly there was a dominance of neutral-alkaline soils that is mainly due to the low-rainfall and high level of reference evapotranspiration in this Mediterranean zone, where there is little leaching of the baseforming cations to the lower soil horizons (Casanova et al., 2013).

Soil samples showed that soil organic matter (OM) contents were: very low ( $13 \%$ of the total), low $(68 \%$ of the total), medium (13\% of the total) and high ( $6 \%$ of the total). It is important to note that in these soils the highest $\mathrm{OM}$ levels were found where farmers have been incorporated the maize residues for several years ( $>5 \mathrm{yr}$ ); in contrast the soils with very low OM contents were found where farmers usually burn the crop residues after the grain harvest. In general the soils in the zone studied show low OM levels (mean $2.17 \%$ ), which is linked to the biological degradation of the soils due to conventional tillage, a high OC decomposition rate and the low recycling of plant residues (Salazar et al., 2011a; Casanova et al., 2012; Martínez et al., 2013). 
Table 2. Chemical soil ranges related to the index of nutrient availability

\begin{tabular}{lllll}
\hline \multirow{2}{*}{ Soil analysis } & \multicolumn{4}{c}{ Class } \\
\cline { 2 - 5 } & Very low & low & medium & high \\
\hline Mineral N $\left(\mathrm{mg} \mathrm{kg}^{-1}\right)^{\mathrm{a}}$ & $<10$ & $11-20$ & $21-40$ & $>41$ \\
P-Olsen $\left(\mathrm{mg} \mathrm{kg}^{-1}\right)^{\mathrm{a}}$ & $<3$ & $4-7$ & $8-18$ & $>18$ \\
Available $\mathrm{K}\left(\mathrm{mg} \mathrm{kg}^{-1}\right)^{\mathrm{a}}$ & $<50$ & $50-80$ & $81-120$ & $>120$ \\
Exchangeable Ca $\left(\mathrm{cmol}_{\mathrm{ckg}} \mathrm{kg}^{-1}\right)^{\mathrm{a}}$ & $<2$ & $2-4$ & $4.1-8.0$ & $>8$ \\
Exchangeable Mg $\left(\mathrm{cmol}_{\mathrm{ckg}} \mathrm{kg}^{-1}\right)^{\mathrm{a}}$ & $<0.2$ & $0.2-0.40$ & $0.5-0.8$ & $>0.8$ \\
Extractable boron $\left(\mathrm{mg} \mathrm{kg}^{-1}\right)^{\mathrm{b}}$ & $<0.2$ & $0.2-0.5$ & $0.6-1.0$ & $>1$ \\
Cu-DTPA $\left(\mathrm{mg} \mathrm{kg}^{-1}\right)^{\mathrm{b}}$ & $<0.1$ & $0.1-0.29$ & $0.3-0.5$ & $>0.5$ \\
Fe-DTPA $\left(\mathrm{mg} \mathrm{kg}^{-1}\right)^{\mathrm{b}}$ & $<1$ & $1.1-2.5$ & $2.5-4.5$ & $>4.5$ \\
Mn-DTPA $\left(\mathrm{mg} \mathrm{kg}^{-1}\right)^{\mathrm{b}}$ & $<0.2$ & $0.2-0.5$ & $0.6-1.0$ & $>1$ \\
Zn-DTPA $\left(\mathrm{mg} \mathrm{kg}^{-1}\right)^{\mathrm{b}}$ & $<0.25$ & $0.25-0.50$ & $0.51-1$ & $>1$ \\
Soil organic matter $(\%)^{\mathrm{a}}$ & $<1$ & $1.0-2.5$ & $2.6-5.0$ & $>5$ \\
\hline
\end{tabular}

a Soil standard for Soil and Water Chemistry Laboratory at University of Chile.

${ }^{\mathrm{b}}$ Rodríguez (1993).

Table 3. Net nitrogen $(\mathrm{N})$ mineralisation potential of soils in central Chile

\begin{tabular}{lc}
\hline \multicolumn{1}{c}{ Soil management and N recycling } & Net N \\
& mineralisation $^{\mathrm{a}}$ \\
\hline Crop rotation with low yields, $>$ 4 years after pasture & $---\mathrm{kg} \mathrm{N} \mathrm{ha}^{-1}---$ \\
Crop rotation with high yields, > 4 years after pasture & $40-60$ \\
Crop rotation, 2-4 years after pasture & $60-80$ \\
1 year after degraded pasture & $80-100$ \\
1-year after high quality pasture & $100-120$ \\
\hline
\end{tabular}

aAdapted from Matus and Rodríguez (1994) and Rodríguez et al. (2001). 
Table 4. Pearson correlation matrix for clay, $\mathrm{pH}$, soil organic matter $(\mathrm{OM})$, nitrogen $(\mathrm{N})$, phosphorus $(\mathrm{P})$, potassium $(\mathrm{K})$, calcium $(\mathrm{Ca})$, magnesium $(\mathrm{Mg})$, boron $(\mathrm{B})$, copper $(\mathrm{Cu})$, iron $(\mathrm{Fe})$, manganese $(\mathrm{Mn})$ and zinc $(\mathrm{Zn})$. " apvalue $<0.001$ was taken as a threshold to select the most significant variables (shown in bold).

\begin{tabular}{|c|c|c|c|c|c|c|c|c|c|c|c|c|}
\hline Variable & $\mathrm{pH}$ & $\mathrm{OM}$ & $\mathrm{N}$ & $\mathrm{P}$ & $\mathrm{K}$ & $\mathrm{Ca}$ & $\mathrm{Mg}$ & B & $\mathrm{Cu}$ & $\mathrm{Fe}$ & $\mathrm{Mn}$ & $\mathrm{Zn}$ \\
\hline Clay & -0.087 & 0.204 & 0.127 & 0.110 & 0.232 & $0.675^{*}$ & $0.778^{*}$ & $0.579^{*}$ & 0.109 & -0.019 & 0.317 & 0.241 \\
\hline $\mathrm{pH}$ & & -0.196 & 0.203 & -0.161 & 0.203 & -0.051 & 0.017 & -0.127 & -0.367 & $-0.821^{*}$ & -0.001 & -0.388 \\
\hline $\mathrm{OM}$ & & & -0.003 & 0.222 & -0.003 & 0.301 & 0.107 & 0.447 & 0.014 & 0.318 & 0.380 & $0.623^{*}$ \\
\hline $\mathrm{N}$ & & & & 0.156 & -0.225 & -0.169 & -0.184 & 0.202 & 0.028 & -0.163 & 0.003 & -0.192 \\
\hline$P$ & & & & & 0.133 & 0.143 & 0.035 & 0.349 & 0.086 & 0.318 & 0.247 & 0.316 \\
\hline K & & & & & & 0.275 & 0.284 & 0.419 & 0.061 & 0.186 & 0.298 & 0.274 \\
\hline $\mathrm{Ca}$ & & & & & & & $0.849^{*}$ & 0.429 & 0.052 & 0.006 & 0.169 & 0.384 \\
\hline $\mathrm{Mg}$ & & & & & & & & 0.359 & -0.082 & -0.043 & 0.174 & 0.188 \\
\hline B & & & & & & & & & 0.204 & 0.100 & 0.439 & 0.527 \\
\hline $\mathrm{Cu}$ & & & & & & & & & & 0.350 & 0.096 & 0.564 \\
\hline $\mathrm{Fe}$ & & & & & & & & & & & 0.117 & 0.474 \\
\hline Mn & & & & & & & & & & & & 0.360 \\
\hline
\end{tabular}

Figure 2a-b shows box plots for macronutrient content of soils. N levels were mainly very low ( $62 \%$ of the total), although low (19\% of the total) and medium (19\% of the total) levels of available $\mathrm{N}$ contents of soil were also found. These results suggest that net $\mathrm{N}$ mineralisation during early spring is negative, because soil temperatures $\left(<10^{\circ} \mathrm{C}\right)$ are not in the optimum range $\left(25-35^{\circ} \mathrm{C}\right)$ to facilitate mineralisation-nitrification. Olsen-P values were mostly high ( $55 \%$ of the total) and medium $(39 \%$ of the total), whereas fewer soil samples had low (3\% of the total) and very low (3\% of the total), which suggested that $\mathrm{P}$ over-fertilisation has been building up a high $\mathrm{P}$ status in these soils. Soil available K were typically high ( $91 \%$ of the total), with very few cases of very low (3\% of the total), low (3\% of the total) and medium (3\% of the total), largely due to $\mathrm{K}$ fertilisation, the high $\mathrm{K}$ source from the parental material and the low risk of $\mathrm{K}$ leaching in these soils.
These macronutrients (N-P-K) did not show any significant $(p>0.001)$ relationship with other variables in the soil according to the Pearson correlation matrix (Table 4). This suggests that available $\mathrm{N}\left(\mathrm{NO}_{3}+\mathrm{NH}_{4}\right)$ content depends on other soil variables than those included in Table 4, such as $\mathrm{C} / \mathrm{N}$ ratio, temperature, soil moisture content, soil aeration and population of soil microorganisms, which were not considered in this study. Similarly, $\mathrm{P}$ and $\mathrm{K}$ content may depend more on corresponding $\mathrm{P}$ and $\mathrm{K}$ fertilisation rates applied during previous years rather than the soil variables considered in the correlation analysis (Table 4).

About $55 \%$ of the total number of samples had high levels of exchangeable $\mathrm{Ca}$, with a number of cases of medium ( $42 \%$ of the total) and few samples with low (3\% of the total) levels. Most soil samples had high levels of exchangeable $\mathrm{Mg}$ ( $78 \%$ of the total), with few cases of medium (19\% of the total) and low (3\% of the total) levels. Clearly $\mathrm{Ca}$ and $\mathrm{Mg}$ 
status are directly related to the cation supply from parent material and the low amount of precipitation in a Mediterranean climate, where cation losses by leaching are small (Casanova et al., 2013). In addition, exchangeable $\mathrm{Ca}$ and $\mathrm{Mg}$ showed a strong positive correlation $(p<0.001)$ with the clay content of the soil (Table 4), which further correlates with the premise that soil with a high clay content presents a high cation exchange capacity (Bergaya et al., 2013).

Figure 1c-dshows the box plots for microelements content in the soils. A high extractable B concentration ( $>1 \mathrm{mg}$ extractable $\mathrm{B} \mathrm{kg}^{-1}$ ) was found in all the soil samples analysed. Clearly extractable B had a strong positive correlation $(p<0.001)$ with the clay content, because finertextured soils retain B for longer periods than coarsertextured soils due to B adsorption by clays (FAO 2006). All the soil samples showed high extractable Fe concentrations $\left(>16 \mathrm{mg}\right.$ extractable $\mathrm{Fekg}^{-1}$ ). In addition, soil extractable $\mathrm{Fe}$ concentrations showed a strong negative correlation $(p<0.001)$ with increments of soil $\mathrm{pH}$ (Table 4). It is well

a)

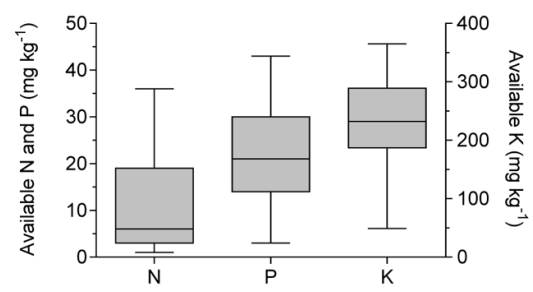

c)

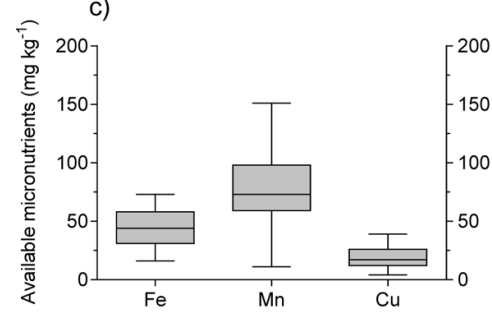

known that low soil $\mathrm{Fe}$ availability is most often observed in high pH soils (Rashid and Ryan, 2004). Soil extractable Mn concentrations were high ( $>10$ mg extractable $\mathrm{Mnkg}^{-1}$ ) and did not present any strong correlation $(p>0.001)$ with other soil characteristics. It may suggest that other soil factors are affecting soil Mn availability such as soil water content and redox potential (Kögel-Knabner et al., 2010). All the soil samples had high extractable $\mathrm{Cu}$ concentrations ( $>4 \mathrm{mg}$ extractable $\mathrm{Cu} \mathrm{kg}^{-1}$ ), although $\mathrm{Cu}$ availability does not show a clear correlation with $\mathrm{pH}$ and other factors. This may be related to $\mathrm{Cu}$ contamination of irrigated soils due to copper mining activities or of natural origin from the weathering of rocks containing $\mathrm{Cu}$ (Casanova et al., 2013). Soil extractable $\mathrm{Zn}$ levels were mainly high (68\% of the total) and medium (32\% of the total). Extractable $\mathrm{Zn}$ contents on soils showed a strong positive correlation $(p<0.001)$ with OM (Table 4). This is consistent with the literature that points out that $\mathrm{Zn}$ forms stable complexes with $\mathrm{OM}$, where mainly humic and fulvic acid fractions are prominent in $\mathrm{Zn}$ adsorption (FAO,2006).

b)

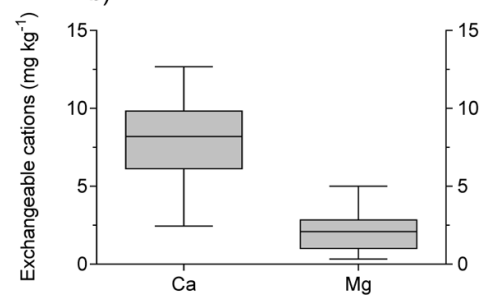

d)

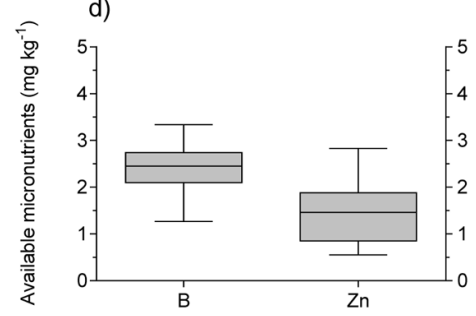

Figure 1. Variability of:a) available nitrogen $(\mathrm{N})$, phosphorus $(\mathrm{P})$ and potassium $(\mathrm{K})$; b) exchangeable calcium (Ca) and magnesium $(\mathrm{Mg})$; c) availableiron (Fe), manganese (Mn) and copper (Cu); and d) available boron (B) and zinc ( $\mathrm{Zn}$ ) found in the maize farms studied $(n=31)$. The box plot indicates the average, $25 \%$ and $75 \%$ quartiles and maximum and minimum values observed. 


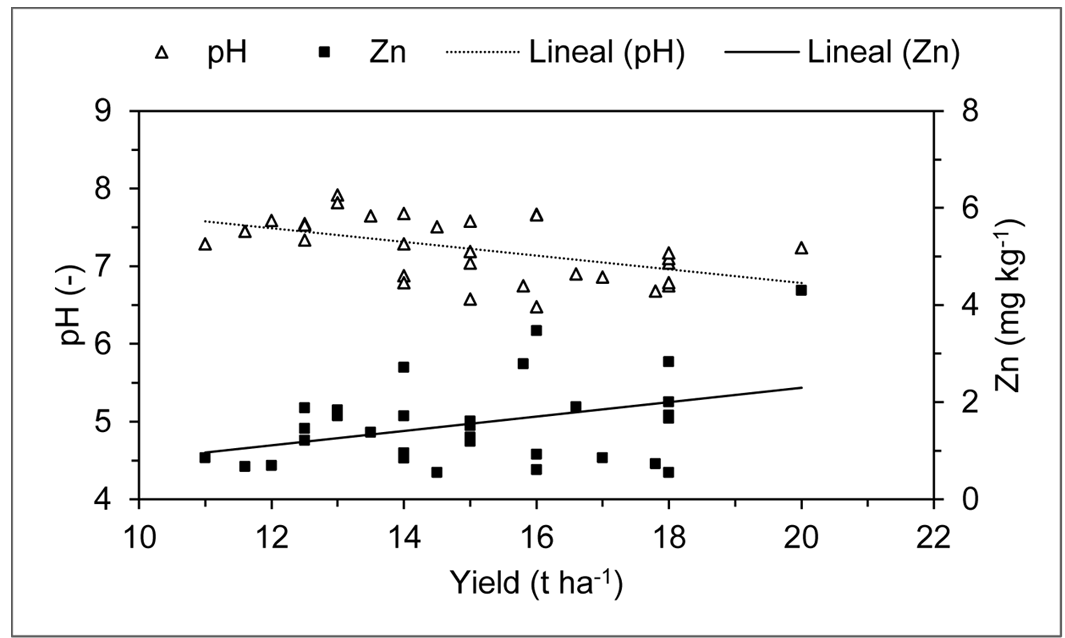

Figure 2. Relationship between maize yield and $\mathrm{pH}-\mathrm{Zn}$ levels $(\mathrm{n}=31)$.

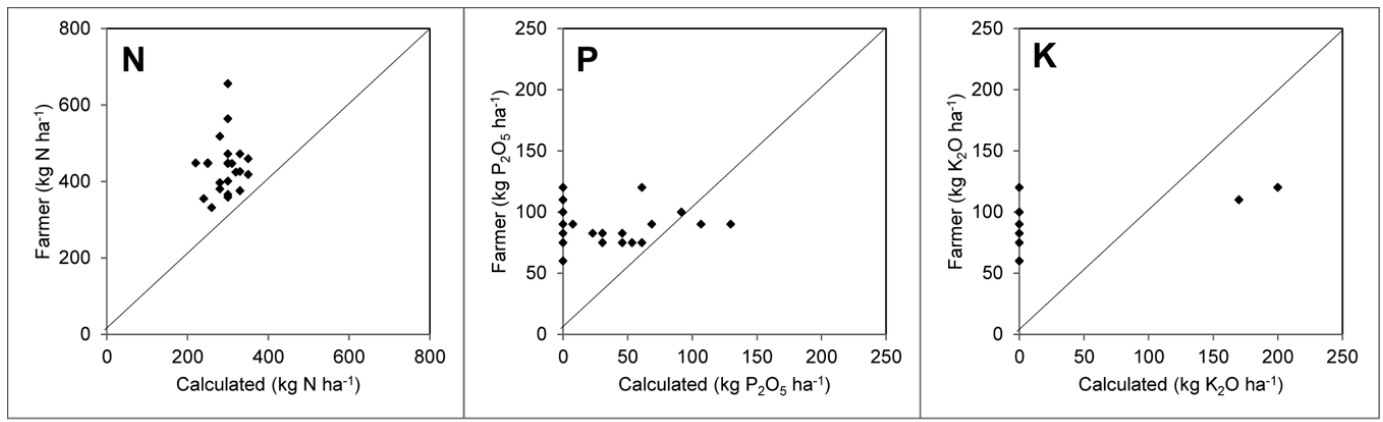

Figure 3. Calculated and observed values of nitrogen $(N)$, phosphorus $(P)$ and potassium $(K)$ in maize farms $(n=31)$. Dots under the $1: 1$ line represent under-fertilisation by the farmers and vice versa.

\subsection{Relationship between maize yield and nutrient} status on soils

Equation 5 shows the regression model for maize yield generated through multiple regression analysis using the data from the farms studied $(n=31)$. This had seven explanatory variables that yielded an adjusted coefficient of determination $\left(\mathrm{R}^{2}{ }_{a d j}\right)$ of 0.59 .
Yield $=368-25.2 \mathrm{pH}+17.3 \mathrm{Zn}-0.0828 \mathrm{~K}+1.67$ MO - 0.452 P - $0.303 \mathrm{Mn}-0.654 \mathrm{Cu}$

Soil $\mathrm{pH}$ was negatively correlated to yield, related to the fact than when soil $\mathrm{pH}$ increases there is a decrease in the availability of some micronutrients. It is well known that maize suffers from micronutrient deficiencies, such as Zn (Rashid and Ryan, 2004). For instance in the regression analysis, $\mathrm{Zn}$ availability 
was positively correlated to yield. Although we found high levels of $\mathrm{Zn}\left(>1 \mathrm{mg} \mathrm{Zn}-\mathrm{DTPA} \mathrm{kg}^{-1}\right)$ ranging between 0.6 and $4.3 \mathrm{mg} \mathrm{Zn-DTPA} \mathrm{kg}{ }^{-1}$ (mean=1.6 mg Zn-DTPA kg-1, $\mathrm{n}=31$; Figure 1d), these regression results suggest that there are still increases in the maize yields when the soil levels of $\mathrm{Zn}$ are over $1 \mathrm{mg} \mathrm{Zn-}$ DTPA $\mathrm{kg}^{-1}$. Therefore, the $\mathrm{Zn}$ medium-high status level currently used in this study (Table 2) is not a good predictor of maize grain yield. These results suggest that in neutral-alkaline soils cultivated with maize and high inputs of N-P-K, there may be a maize yield response to $\mathrm{Zn}$ applications. Clearly $\mathrm{pH}$ and $\mathrm{Zn}$ had the highest impact on maize yield as is shown in Figure 2 , which illustrates that yields are decreasing when $\mathrm{pH}$ increases, but that the opposite occurs when $\mathrm{Zn}$ level are increasing. Kanwal et al. (2010) in a study in Pakistan (soil $\mathrm{pH}=8.0$ ) showed that with an initial value of $0.7 \mathrm{mg} \mathrm{Zn-DTPA} \mathrm{kg}^{-1}$ the maize responded to $\mathrm{Zn}$ application even when the doses were between 6-18 $\mathrm{kg} \mathrm{ZnSO}_{4} \mathrm{ha}^{-1}$. Similarly, a number of studies have shown that if there is a good N-P-K status on soils the application of $\mathrm{Zn}$ would enhance the maize grain yield in other arid and semiarid regions (Manzeke et al., 2012; Mena et al., 2013). In addition, further studies are needed to develop an equation for calculating $\mathrm{Zn}$ fertilisation rates based on Zn-DTPA soil levels, which considers factors affecting $\mathrm{Zn}$ availability such as: soil $\mathrm{pH}, \mathrm{Zn}$ adsorption, $\mathrm{OM}$ and interactions with other micronutrients (e.g. $\mathrm{Cu}, \mathrm{Fe}$ and $\mathrm{Mn}$ ).

Other variables had a lower impact on maize yields, such as i) available $\mathrm{K}$ was negatively correlated to yield, which suggests that very high $\mathrm{K}$ levels may generate some antagonism with other cations by depressing the uptake of $\mathrm{NH}_{4}^{+}, \mathrm{Ca}^{2+}$ and $\mathrm{Mg}^{2+}$; ii) in a similar way, available $\mathrm{P}$ was negatively correlated to yield, which may indicate that high levels of available $\mathrm{P}$ may produce antagonism with other elements such as $\mathrm{Zn}$; iii) on the other hand, OM was positively correlated to maize yield, confirming the conclusions of extensive research regarding the benefits of $\mathrm{OM}$ for crop production through improving soil fertility, soil physical properties and soil biodiversity (Lal, 2009) and; iv) in contrast, $\mathrm{Mn}$ and $\mathrm{Cu}$ were negatively correlated to maize yield, which suggest that excessive amounts of these micronutrients may generate toxicity in maize growing.

\subsection{Comparison between common farmer practices and calculated $N-P$ - K fertiliser application rates}

Figure 3shows a scatter diagram comparison between calculated $\mathrm{N}$ (Equation. 2), $\mathrm{P}$ (Equation 3 ) and $\mathrm{K}$ (Equation 4) fertiliser rates and common N-P-K fertiliser rates reported by farmers from the 31 fields included in this study. Clearly, all maize fields were $\mathrm{N}$ over-fertilised, when farmer applied $\mathrm{N}$ rates higher than the calculated $\mathrm{N}$ rates (maximum recommended of $350 \mathrm{~kg} \mathrm{~N} \mathrm{ha}^{-1}$ ), and over-fertilisation amount ranged between 60 and $360 \mathrm{~kg} \mathrm{~N} \mathrm{ha}^{-1}$. For P fertilisation rates, $94 \%$ of the farmers over-fertilised and $6 \%$ under-fertilised, and over-fertilisation amount ranged between 10 and $120 \mathrm{~kg} \mathrm{P}_{2} \mathrm{O}_{5} \mathrm{ha}^{-1}$, whereas under-fertilisation amount ranged between 15 and 40 $\mathrm{kg} \mathrm{P}_{2} \mathrm{O}_{5} \mathrm{ha}^{-1}$. In general, the soils in this Mediterranean zone showed high soil $\mathrm{K}$ levels (> $120 \mathrm{mg} \mathrm{kg}^{-1}$ available K) (Casanova et al., 2013). In our study most fields were $\mathrm{K}$ over-fertilised, except in three fields ( $n=31)$ where $K$ fertilisation rates were lower than the $\mathrm{K}$ calculated doses, with over-fertilisation amount ranging between 60 and $120 \mathrm{~kg} \mathrm{~K}_{2} \mathrm{O} \mathrm{ha}^{-1}$, whereas under-fertilisation ranged between 60 and $195 \mathrm{~kg} \mathrm{~K}_{2} \mathrm{O} \mathrm{ha}^{-1}$.

The resulting $\mathrm{N}$ recommendation according to Equation 2 assumed that the soil supplies a constant proportion of plant available $\mathrm{N}$, however, previous management of $\mathrm{N}$ fertilisation indicated that this assumption is not correct (see Table 3 ) and there is an additional risk for $\mathrm{N}$ over or under fertilisation. 
Although, the latter $\mathrm{N}$ mass balance approach for $\mathrm{N}$ rates calculations have been widely accepted for Chilean soils, it is necessary to calibrate an $\mathrm{N}$ test that allows an $\mathrm{N}$ site-specific recommendation according with the temporal and spatial variability of $\mathrm{N}$ concentration in the soil under local conditions (Montemurro et al., 2006; Mulvaney et al., 2006). Similarly, Berenguer et al. (2009) in a study of $\mathrm{N}$ fertilisation of irrigated maize under Mediterranean conditions recommended that soil $\mathrm{N}$ content before planting and fertilising should always be taken into account in $\mathrm{N}$ fertilisation calculations.

Although the amounts of $\mathrm{P}$ and $\mathrm{K}$ calculated using the critical soil value approach are in accordance with local experience in recent decades, new maize hybrids which have been introduced in the crop system must also be taken into account. These hybrids along with optimal climate conditions and irrigation during the growing season may allow farmers in this zone to obtain yields of over $20 \mathrm{t} \mathrm{ha}^{-1}$. The latter means, that the actual $\mathrm{P}$ and $\mathrm{K}$ critical soil values and the corresponding fertiliser responses should be updated using field experiments.

It is important to note that other management practices may affect N-P-K fertiliser calculations. Salazar et al. (2013) in a survey of maize production in the O'Higgins Regions found that: i) most fields showed a high degree of soil physical degradation, mainly plow pan, which may restrict the root development and in consequence nutrient absorption; and ii) low irrigation efficiency $(<45 \%)$ that may favour high water percolation and surface runoff, which are directly related to $\mathrm{N}$ and $\mathrm{P}$ losses from the soils, reducing $\mathrm{N}$ and $\mathrm{P}$ use efficiency. In this sense, Di Paolo and Rinaldi (2008) in a study of yield response of maize to irrigation and $\mathrm{N}$ fertilisation in Mediterranean conditions noted that there was a significant interaction between $\mathrm{N}$ fertilisation rate and irrigation for maize yield.
3.4. Environmental impacts of $N$ and $P$ overfertilisation

We found that all $\mathrm{N}$ rates exceeded yield potential indicating that residual $\mathrm{N}$, mainly $\mathrm{NO}_{3}^{-}$, may leach if there is sufficient water to lead below the root zone. The $\mathrm{NO}_{3}^{-}$leaching rates are high and cause groundwater contamination, particularly in coarsetextured soils with low water retention capacity (Salazar et al., 2009).

Similarly, most of the time, excessive $\mathrm{P}$ rates in addition to the continued use of $\mathrm{P}$ fertilisers greater than crop needs could produce a build-up of $\mathrm{P}$ in soil. This excessive $\mathrm{P}$ enrichment in soils can increase the potential for losses of P to surface water by surface runoff and groundwater by leaching (Salazar et al., 2011b).

Therefore $\mathrm{N}$ and $\mathrm{P}$ over-fertilisation can increase the risk of $\mathrm{N}$ and $\mathrm{P}$ soil saturation where later irrigation furrow runoff can transfer $\mathrm{N}$ and $\mathrm{P}$ to nearby surface waters during the growing season (Casanova et al., 2013). In addition, these fields are fallow during the autumn-winter season, when intensive precipitation events occur, increasing the risk of movement of residual $\mathrm{N}$ and $\mathrm{P}$ from the fields towards surface and subsurface waters. Similarly, in other Mediterranean zones, it has been reported that most $\mathrm{N}$ and $\mathrm{P}$ off loads from agricultural areas were generated during the winter season (Casalí et al., 2008). Therefore mitigation measures are needed to reduce the high risk of $\mathrm{N}$ and $\mathrm{P}$ diffuse pollution, such as optimal $\mathrm{N}$ and $\mathrm{P}$ fertiliser application, improvements in irrigation efficiency, the use of slow release fertiliser and the setting of buffer strips. Regarding the latter, in a pilot study in the zone, Tapia and Villavicencio (2007) showed promising results in attempts to reduce $\mathrm{N}$ and $\mathrm{P}$ loads by using buffer strips of trees and pastures to protect surface water. Recently, Gabriel et al. (2012) replacing bare fallow with cover crops, in maize 
cropping systems have been successfully reduced $\mathrm{N}$ leaching during winter period in other Mediterranean Regions. In addition, Lu et al. (2010) recommend that the application of chemical fertilizer and maize straw with a wide $\mathrm{C} / \mathrm{N}$ ratio is an important measure for reducing the $\mathrm{N}$ surplus and in consequence to reduce its loss.

\section{Conclusions}

We found that in the soils cultivated with maize in central Chile under Mediterranean conditions there was a dominance of neutral-alkaline soils with low $\mathrm{OM}$, low $\mathrm{N}$ levels, high $\mathrm{P}$, high cations ( $\mathrm{Ca}$ and $\mathrm{Mg}$ ) and high micronutrients $(\mathrm{B}, \mathrm{Cu}, \mathrm{Mn}, \mathrm{Fe}$ and $\mathrm{Zn})$ levels.

Regression models explained at least $59 \%$ of the variation in maize yields, based on adjusted determination coefficient $\left(\mathrm{R}_{a d j}^{2}\right)$ calculations, which showed that soil $\mathrm{pH}$ and $\mathrm{Zn}$ content were identified as the most important variables controlling yield. Results suggest that in neutral-alkaline soils cultivated with maize and high inputs of N-P-K, there may be a maize yield response to $\mathrm{Zn}$ applications.

During maize growing season in this Mediterranean zone a combination of two factors: soil $\mathrm{N}$ and $\mathrm{P}$ saturation due over-fertilisation and furrow irrigation systems that move this nutrient surplus that enter water bodies convert maize field in an important nonpoint source pollution that damage downstream users and environments. Therefore mitigation measures are needed such as optimal $\mathrm{N}$ and $\mathrm{P}$ fertiliser application, improvements in irrigation efficiency, the use of slow release fertilisers and the setting of buffer strips.

Indeed in the Mediterranean zones of Chile under irrigation, higher maize grain yields represent the greatest opportunity for reducing per-unit production cost, where fertiliser management is a key factor for increasing these yields. However, the unacknowledged importance of assessing nutrient soil status and the consequential risk of the incorrect application of fertilisers may be a great constraint to achieving this objective.

\section{Acknowledgments}

The authors thank the Departamento de Ingeniería y Suelos at the Universidad de Chile and the Cooperativa Intercomuna Campesina de Peumo (COOPEUMO) for supporting this study. This research was partially funded by FONDECYT de Iniciación 2011 grant $\mathrm{N}^{\circ}$ 11110464.

\section{References}

Berenguer, P., Santiveri, F., Boixadera, J., Lloveras, J. 2009. Nitrogen fertilisation of irrigated maize under Mediterranean conditions. Eur. J. Agron. $30,163-171$.

Bergaya, F., Lagaly, G., Vayer, M. 2013. Cation and Anion Exchange. In: F. Bergaya, G.Lagaly (eds). Developments in Clay Science. Elsevier BV, Amsterdam, 333-329pp.

Casalí, J., Gastesi, R., Álvarez-Mozos, J., De Santisteban, L.M., Del Valle de Lersundi, J., Giménez, R., Larrañaga, A., Goñi,M., Agirre, U., Campo, M.A., López, J.J., Donézar,M. 2008. Runoff, erosion, and water quality of agricultural watersheds in central Navarre (Spain). Agr.Water Manage. 95, 1111-1128.

Casanova, M., Salazar, O., Nájera, F., Seguel, O., Villarroel, R., Leiva, C.2012. Long-term monitoring of soil fertility for agroforestry combined with water harvesting in Central Chile. Arch.Agron.Soil Sci. 58(S1), 165-169.

Casanova, M., Salazar, O., Seguel, O., Luzio, W. 2013. The Soils of Chile, World Soils Book Series. Springer Science+ Business Media, Dordrecht. $185 \mathrm{p}$. 
CIREN. 2006. Estudio agrológico VI Región Materiales y símbolos. Centro de Información en Recursos Naturales (CIREN), Publicación N 114 , Santiago. 562 p.

Di Paolo, E., Rinaldi, M. 2008. Yield response of corn to irrigation and nitrogen fertilization in a Mediterranean environment. Field Crop Res. 105, 202-210.

FAO. 2006. Plant nutrition for food security: a guide for integrated nutrient management. Food and Agriculture Organization of the United Nations, FAO, Rome .348 p.

Fuentes, I., Casanova, M., Seguel, O., Nájera, F., Salazar, O. 2014. Morpho-physical pedotransfer functions for groundwater pollution by nitrate leaching in Central Chile. Chil. J. Agr. Res. 74, 340-348

Gabriel, J.L., Muñoz-Carpena, R., Quemada, M. 2012. The role of cover crops in irrigated systems: Water balance, nitrate leaching and soil mineral nitrogen accumulation. Agric.Ecosys. Environ. $155,50-61$.

Kanwal, S., Ranjh, R.A.M., Ahmad, R. 2010. Zinc partitioning in maize grain after soil fertilization with zinc sulphate. Int.J.Agr. Biol. 12, 299-302.

Kögel-Knabner, I., Amelung, W., Cao, Z., Fiedler, S., Frenzel, P., Jahn, R., Kalbitz, K., Kölbl, A., Schloter, M. 2010. Biogeochemistry of paddy soils. Geoderma. 157, 1-14.

Lal, R.2009. Challenges and opportunities in soil organic matter research. Eur. J. Soil Sci. 60, 158169.

Lu, C., Ma. J., Chen, X., Zhang, X., Shi, Y., Huang, B. 2010. Effect of nitrogen fertilizer and maize straw incorporation on $\mathrm{NH}_{4}^{+15} \mathrm{~N}$ and $\mathrm{NO}_{3}{ }^{-15} \mathrm{~N}$ accumulation in black soil of northeast china among three consecutive cropping cycles. J. Soil Sci. Plant Nutr. 10, 444-453.
Manzeke, G.M., Mapfumo, P., Mtambanengwe, F., Chikowo, R., Tendayi, T., Cakmak, I. 2012 Soil fertility management effects on maize productivity and grain zinc content in small holder farming systems of Zimbabwe. Plant Soil. 361, 57-69.

Martínez, E., Fuentes, J.P., Pino, V., Silva, P., Acevedo, E. 2013. Chemical and biological properties as affected by no-tillage and conventional tillage systems in an irrigated Haploxeroll of Central Chile. Soil Till. Res. 126, 238-245.

Matus, F., Rodríguez, J. 1994. A simple model for estimating the contribution of nitrogen mineralization to the nitrogen supply of crops from stabilized pool of soil organic matter and recent organic input. Plant Soil. 162, 259-271.

Meena, S.K., Mundra, S.L., Singh, P. 2013. Response of maize (Zea mays) to nitrogen and zinc fertilization. Indian J. Agron. 58, 127-128.

Montemurro, F., Maiorana, F., Ferri, D., Convertini, G. 2006. Nitrogen indicators, uptake and utilization efficiency in a maize and barley rotation cropped at different levels and sources of $\mathrm{N}$ fertilization. Field Crop Res. 30, 114-124.

Mulvaney, R.L., Khan, S.A., Ellsworth, T.R. 2006. Need for a soil based approach in managing nitrogen fertilizers for profitable corn production. Soil Sci. Soc. Am. J. 70, 172-182.

Opazo, J.D., Luchsinger, A., Neira, O. 2008. Soil and plant factors for determine the nitrogen fertilization on sweet corn in the central zone of Chile. Idesia. 26, 53-58.

Quemada, M., Baranski, M., de Lange, M.N.J., Vallejo, A., Cooper, J.C. 2013. Meta-analysis of strategies to control nitrate leaching in irrigated agricultural systems and their effects on crop yield. Agric. Ecosys. Environ. 174, 1-10. 
Rashid, A., Ryan, J. 2004. Micronutrient constraints to crop production in soils with Mediterraneantype characteristics: a review. J. Plant Nutri. 27, 959-975.

Robertson, G.P., Vitousek, P.M. 2009. Nitrogen in agriculture: balancing the cost of an essential resource. Annu.Rev. Env.Resour. 34, 97-125.

Rodríguez, J., Pinochet, D., Matus, F. 2001. Fertilización de los cultivos. LOM Ediciones, Santiago. $117 \mathrm{p}$.

Sadzawka, A., Grez, R., Carrasco, M.A., Mora, M. 2006. Métodos recomendados para suelos chilenos (Methods recommended for Chilean Soils). Comisión Nacional de Normalización y Acreditación, Sociedad Chilena de la Ciencia del Suelo, Santiago, 164 p.

Salazar, O.,Wesström, I., Youssef, M.A., Skaggs, R.W., Joel, A. 2009. Evaluation of the DRAINMOD-N II model for prediction nitrogen losses in loamy sand under cultivation in south-east. Sweden. Agr. Water Manage. 96, 267-281.

Salazar, O., Casanova, M., Kätterer, T. 2011a. The impact of agroforestry combined with water harvesting on soil carbon and nitrogen stocks in central Chile evaluated using the ICBM/N model. Agric. Ecosys. Environ. 140, 123-136.

Salazar, O., Wesström,I., Joel, A. 2011b. Identification of hydrological factors controlling phosphorus concentration in drainage water in sandy soils. J. Soil Sci. Plant Nutr. 11, 31-46.
Salazar, O., Rojas, C., Soto, C. 2013. Diagnóstico sectorial y acuerdo de producción limpia: Productores de maíz de la Región de Libertador General Bernardo O‘Higgins. Consejo Nacional de Producción Limpia, Rancagua, Chile, 217 p.

Salazar, O.,Vargas, J., Nájera, F.Seguel, O., Casanova, M. 2014. Monitoring of nitrate leaching during flush flooding events in a coarse-textured floodplain soil. Agr. Water Manage. 146, 218-227.

Salmerón, M., Isla, R., Cavero, J. 2011. Effect of winter cover crop species and planting methods on maize yield and $\mathrm{N}$ availability under irrigated Mediterranean conditions. Field Crop Res. 123, 89-99.

Soil Survey Staff. 2014. Keys to Soil Taxonomy, 12th ed. USDA-Natural Resources Conservation Service, Washington, DC.

Sandoval, M., Dörner, J., Seguel, O., Cuevas, J., Rivera, D. 2012. Métodos de análisis físicos de suelos (Methods of soil physical analyses). Universidad de Concepción, Publicaciones Departamento de Suelos y Recursos Naturales No. 5, Chillán, Chile, 80 p.

Tapia, F., Villavicencio P. 2007. Uso de biofiltros para mejorar la calidad del agua de riego. Proyecto FONSAG: "Evaluación de biofiltros para reducir la contaminación difusa en aguas de riego de las regiones VI y VII". Instituto de Investigaciones Agropecuarias, Boletín INIA No.170, Santiago. $128 \mathrm{p}$. 